\title{
Comparison of variables influence on adhesive bonds strength calculations
}

\section{Miroslav Müller, Petr Valášek}

Department of Material Science and Manufacturing Technology, Faculty of Engineering, Czech University of Life Sciences in Prague. E-mail: muller@tf.czu.cz.

In the sphere of the metal sheet bonding namely single overlapped adhesive bonds are used. Their production costs less and they confirm strength requirements in many cases. The great part of the single overlapped adhesive bonds research was focused on a geometrical setting of adhesive bonds, an adhesive layer thickness and on mechanical properties of adherents. The analysis of the adhesive bonds strength calculations is ignored. The calculations stated according to the standards are often simplified and they do not take into the regard an adhesive bonded material and an adhesive layer thickness. The aim of the research is to define if the adhesive bond strength calculated according to the standard ČSN EN 1465 is the same as the reduced strength according to Mohr`s and Guess state of stress theory regarding the adherent deformation and the adhesive layer thickness in the calculation. The issue is solved by the experimental research and statistical testing.

Keywords: adhesive layer thickness, bonding material, reduced tensile shear strength, tensile shear strength

Acknowledgement

Supported by Internal grant agency of Faculty of Engineering, Czech University of Life Sciences in Prague

\section{Reference}

[1] ADAMS, Robert, D.; COMYN, Joseph; WAKE, William. Structural adhesive joints in engineering. $2^{\text {nd }}$ ed. London: Chapman \& Hall, 1997. 376 pp

[2] KALINCOVÁ, Daniela; KUSMIERCZAK, Sylvia. Vliv metody svařování na tvorbu mikrostruktury svarových spojů. Strojírenská technologie, 2011, vol. 16, no. 3, p. 7 - 13.

[3] MESSLER, Robert. W. Joining of materials and structures from pragmatic process to enabling technology. Burlington: Elsevier, 2004. 815 pp.

[4] MEŠKO, Jozef; FABIAN, Peter; HOPKO, Anton; KOŇÁR, Radoslav. Shape of heat source in simulation program SYSWELD using different types of gases and welding methods. Strojírenská technologie, 2011, vol. 16, no. 5, p. $6-11$.

[5] MÜLLER, Miroslav, HŮRKA, Karel. Vliv teploty prostředí na dobu vytvrzování lepidla v lepeném spoji. Strojírenská technologie, 2006, vol. 12, no. 1, p. 9 - 15 .

[6] VONDROUŠ, Petr; KATAYMA Seiji. Využití vysokorychlostní kamery pro sledování procesu laserového svařování. Strojírenská technologie, 2011, vol. 16, no. 1, p. 34 - 39.

[7] MÜLLER, Miroslav. Proces stárnutí a trvanlivosti garantované výrobcem na hodnocení lepených spojů. Strojírenská technologie, 2011, vol. 16, no. 2, p. 23 - 28.

[8] BROŽEK, Milan; Müller, Miroslav. Mechanické vlastnosti spojů lepených sekundovými lepidly. Strojírenská technologie, 2004, vol. 9, no. 1, p. 9 - 15 .

[9] MÜLLER, Miroslav; NÁPRSTKOVÁ, Nataša. Possibilities and limits of adhesive layer thickness optical evaluation. Manufacturing technology, 2010, vol. 10, no.10, p. 45 -59.

[10] MÜLLER, Miroslav; HERÁK, David. Dimensioning of the bonded lap joint. Research in Agricultural Engineering, 2010, vol. 56, no. 2, p. $59-68$.

[11] MÜLLER, Miroslav; VALÁŠEK, Petr: Interaction of steel surface treatment by means of abrasive cloth and adhesive bond strength, Manufacturing technology, 2010, vol. 10, no. 10, p. 49 -57.

[12] NOVÁK, Martin. Surfaces with high precision of roughness after grinding. Manufacturing technology, 2012, vol. 12 , no.12, p. $66-70$.

[13] NOVÁK, Martin. Surface quality of hardened steels after grinding. Manufacturing technology, 2011, vol. 11, no. 11, p. $55-59$.

[14] BROUGHTON, W. R., et al. Environmental Degradation of Adhesive joints single-lap point [online]. 1999,[cit. 2011-07-22]. Available at:http://www.adhesivestoolkit.com/DocuData/NPLDocuments/P\%20 A\%20J/PAJ\%20Reports/PAJ3\%20Reports/PAJ3\%20Report\%206\%20CMMT(A)196.pdf 
[15] ČSN EN 1465: Adhesives - Determination of tensile lap-shear strength of bonded assemblies. Prague, Czech Standard Institute, 1997. (In Czech)

[16] ČSN ISO 10365: Adhesives. Designation of main failure patterns. Prague, Czech Standard Institute, 1995. (In Czech)

[17] MARGHITU, Dan, B. Mechanical engineer's handbook, Academic Press, 2001, 888 pp.

[18] GRANT, L.D.R.; ADAMS R.D.; LUCAS da SILVA, F.M. Experimental and numerical analysis of single-lap joints for the automotive industry. International Journal of adhesion \& Adhesives, 2009, vol. 29, no. 4, p. 405413. 